\title{
Optimal an extracellular alkaline protease production condition for Pseudomonas aeruginosa
}

\author{
Jianhua Hao, Junzhong Liu, Cui Yuan, Xiaofeng Ji, Mi Sun* \\ Yellow Sea Fisheries Research Institute, Qingdao, 266071, China.
}

Accepted 29 March, 2013

\begin{abstract}
Pseudomonas aeruginosa JM07 which produces an extracellular alkaline protease was isolated from the Yellow Sea in China. The cultural conditions were optimized for maximum enzyme production. Maximum enzyme activity was achieved when the bacterium was grown in soybean meal $(3.5 \%, w / v)$, corn steep meal $\left(1.5 \%\right.$, w/v), $\mathrm{Na}_{2} \mathrm{HPO}_{4}\left(0.4 \%\right.$, w/v), $\mathrm{KH}_{2} \mathrm{PO}_{4}(0.03 \%, \mathrm{w} / \mathrm{v}), \mathrm{Na}_{2} \mathrm{CO}_{3}(0.02 \%, \mathrm{w} / \mathrm{v}), \mathrm{MgSO}_{4}$ $(0.02 \%, \mathrm{w} / \mathrm{v}), \mathrm{CaCl}_{2}(0.2, \mathrm{w} / \mathrm{v})$, at $\mathrm{pH} 7.0$ and $20^{\circ} \mathrm{C}$ over $12 \mathrm{~h}$ incubation period. The enzyme had an optimum $\mathrm{pH}$ of around 10 and maintained its stability over a broad $\mathrm{pH}$ range between 7 and 12 . Its optimum temperature is around $30^{\circ} \mathrm{C}$, and exhibited a stability of up to $40^{\circ} \mathrm{C}$. The enzyme activity was strongly inhibited by DFP, suggesting that it belongs to the family of serine proteases.
\end{abstract}

Key words: Pseudomonas aeruginosa, alkaline protease, by-product.

\section{INTRODUCTION}

Proteases constitute one of the most important groups of industrial enzymes and in recent years, the use of alkaline proteases in a variety of industrial processes involving detergents, food, leather and silk has increased remarkably (Maurer, 2004). Currently, a large proportion of the commercially available alkaline proteases are derived from Bacillus strains (Tekin et al., 2012), although several fungal sources are being increasingly employed (Chellapandi, 2010). 30 to $40 \%$ of the production cost of industrial enzymes is estimated to be accounted for by the cost of the growth medium. Considering this fact, the use of cost-effective growth medium for the production of alkaline proteases from a microbe is especially important, because these enzymes account for approximately $60 \%$ of world-wide enzyme consumption (Deng, 2008). Large quantities of agricultural and agro-industrial residues are generated from diverse agricultural and industrial practices. These residues represent one of the most energyrich resources on the planet (Nigam et al., 2001). For this purpose, soybean meal and corn steep meal were recognized as a potentially useful and cost-effective medium ingredient. The principal objective of this study was to screen for the soybean meal and corn steep, and further to optimize the levels of the screened medium, for alkaline protease production by employing Pseudomonas aeruginosa JM07 along with some biochemical properties of the enzyme. This study is a component of a broader investigation into the influences of cheap raw materials such as soybean meal and corn steep, as determined using statistical methodologies.

\section{MATERIALS AND METHODS}

Microorganism and growth conditions

The organism used in this study was a Pseudomonas species, which was isolated from the Yellow Sea in China. This strain was determined to be a member of Pseudomonas according to its $16 \mathrm{~S}$ rDNA and fatty acids profile (The data are not listed in this article). Bacterial protease was directly determined using a casein agar 
plate during cultivation. The culture media used was Luria-Bertani broth (LB), and the $\mathrm{pH}$ was adjusted to 7 . The medium $(200 \mathrm{ml})$ in $500 \mathrm{ml}$ baffled flasks was inoculated with $1 \mathrm{ml}$ of a 16 hold seed culture, and incubated at $20^{\circ} \mathrm{C}$ with shaking at $200 \mathrm{rpm}$ for $12 \mathrm{~h}$. The cell-free supernatant was recovered by centrifugation (6 000 $\mathrm{rpm}, 4^{\circ} \mathrm{C}, 30 \mathrm{~min}$ ), and used for determining extracellular alkaline protease activity.

To find the best protease production condition, carbon sources including soluble starch, sucrose, glucose, lactose, fructose, maltose, corn steep meal and citric acid were added separately to a fixed concentration of $1.0 \%$. Nitrogen supplement including peptone $(1.5 \%)$, fish meal $(1.5 \%)$, tryptone $(1.5 \%)$, yeast extract $(1.5 \%)$, urea $(1.5 \%)$, soybean mealn $(2.5 \%)$, cotton-seed meal $(1.5 \%)$ and ammonium citrate $(1.0 \%)$ were added separately. The medium that supports the best protease activity was applied in the following investigation of protease characteristics.

\section{Protease assay and purification}

Standard conditions for proteolytic activity assay was assayed using casein (Sigma) as the substrate. Enzyme solution $(200 \mu \mathrm{l})$ was added to $200 \mu$ l of glycine- $\mathrm{NaOH}(\mathrm{pH} 10.4)$ buffer containing $1 \%$ casein, and incubated at $30^{\circ} \mathrm{C}$ for $10 \mathrm{~min}$. The reaction was stopped by adding $400 \mu \mathrm{l} 20 \% \mathrm{w} / \mathrm{v}$ TCA solution. After the preparation stood at room temperature for $10 \mathrm{~min}$, the entire mixture was centrifuged at $12,000 \times \mathrm{g}$ for $10 \mathrm{~min}$. The acid-soluble material was estimated spectrophotometrically at $280 \mathrm{~nm}$. The blank sample was made by adding TCA before the enzyme. The difference in optical density between the sample and the blank was used as the measure of proteolytic activity.

One protease unit was defined as the amount of enzyme that produces $1 \mu \mathrm{gg}$ of tyrosine in $1 \mathrm{~min}$ under the defined assay conditions. The standard curve of tyrosine was determined by the absorbance at $280 \mathrm{~nm}$ as a function of various concentrations of tyrosine, from 0 to $10 \mathrm{mg} / \mathrm{ml}$.

All the following fractionations were done at $4^{\circ} \mathrm{C}$, unless otherwise specified and the chromatography purification was monitored for protein by measuring absorbance at $280 \mathrm{~nm}$.

Step1. The culture was centrifuged at $4000 \mathrm{rpm}$ for $40 \mathrm{~min}$ at $4^{\circ} \mathrm{C}$ to remove cells and insoluble residues, and the culture supernatant was brought to $80 \%$ saturation with ammonium sulphate. The resulting precipitate collected by centrifugation (4 $000 \mathrm{rpm}$ ) was dissolved in $25 \mathrm{mM}$ borate buffer $(\mathrm{pH} \mathrm{10.0)}$, and it was then dialyzed against $2 \mathrm{~L}$ of the same buffer for $48 \mathrm{~h}$, with four changes made at $12 \mathrm{~h}$ intervals.

Step 2. The dialyzed enzyme was loaded onto a cation exchanger (DEAE-Sepharose, Pharmacia, Sweden, $1.5 \times 20 \mathrm{~cm}$ ) equilibrated with $25 \mathrm{mM}$ borate buffer $(\mathrm{pH}$ 10.0). The flow rate was adjusted to $1 \mathrm{ml} \mathrm{min}{ }^{-1}$. The enzyme was eluted from the column using a linear $\mathrm{NaCl}$ gradient $(0-1.0 \mathrm{M})$ and the eluted fractions were collected. These fractions were collected and precipitated by the addition of 0.5 volume of chilled ethanol, and the enzyme precipitated removed by centrifugation at $4000 \mathrm{rpm}$ for $40 \mathrm{~min}$.

Step 3. The protease solution prepared from step 2 loaded on to a Sephacryl S-200 gel filtration column (Pharmacia, Sweden, $1 \mathrm{~cm} \times$ $80 \mathrm{~cm}$ ) equilibrated with $25 \mathrm{mM}$ borate buffer $(\mathrm{pH} \mathrm{10.0)}$. Fractions of the elution were collected at a flow rate of $0.2 \mathrm{ml} \mathrm{min}^{-1}$. The active protease fractions were pooled and storied at $-20^{\circ} \mathrm{C}$.

\section{Temperature and $\mathrm{pH}$}

The partially purified protease was incubated at various temperatures ranging from 0 to $50^{\circ} \mathrm{C}$ for $30 \mathrm{~min}$. The protease activity was measured at $30^{\circ} \mathrm{C}$ in the following buffer systems: $0.1 \mathrm{M}$ sodium acetate ( $\mathrm{pH}$ 4.0-5.5);0.1 M sodium phosphate $(\mathrm{pH} 6.0-7.5) ; 0.1 \mathrm{M}$
Tris- $\mathrm{HCl}(\mathrm{pH} 8.0-9.0) ; 0.1 \mathrm{M}$ glycine- $\mathrm{NaOH}(\mathrm{pH} 9.5-11)$; and $0.1 \mathrm{M}$ sodium carbonate $(\mathrm{pH} 11.5-12.0)$, respectively.

\section{Chemical effects}

The effects of various chemical reagents and metal ions on enzyme activity were examined by incubation the protease solution (in $25 \mathrm{mM}$ borate buffer, $\mathrm{pH} 10.0$ ) with different compounds at $20^{\circ} \mathrm{C}$ for 1 $\mathrm{h}$, and the relative activities were determined under standard assay conditions.

\section{Effects of detergent additives}

The effects of various detergent additives on enzyme activity were examined by incubation of the protease solution (in $25 \mathrm{mM}$ borate buffer, $\mathrm{pH} 10.0$ ) with different compounds at $20^{\circ} \mathrm{C}$ for $1 \mathrm{~h}$, and the relative activities determined under standard assay conditions.

\section{Inhibition tests}

The partially purified protease was incubated with different inhibitors under optimum reaction conditions. Residual activities in the presence of the inhibitors were compared with the controls without inhibitor.

\section{RESULTS AND DISCUSSION}

\section{The organism}

Several bacterial strains secreting alkaline proteases were screened and isolated from the Yellow Sea in China. Among these, one strain Ps. aeruginosa JM107 (The strain identification are not listed in this article) exhibited prominent clear zones around the colonies on casein agar plates indicating that it secretes significant amounts of protease. Some Pseudomonas species produce alkaline extracellular proteases, which are similar to those produced by Bacillus species. Furthermore, because Ps. aeruginosa can grow in alkaline, water-soluble oil, its enzymes must be adapted to function optimally under such extreme conditions. Therefore, Pseudomonas species may also have various industrial applications, including for the synthesis of a broad spectrum of organic molecules in non-aqueous solvents and detergents industry (Sugihara et al., 2002). So this organism was selected for further optimization of the extracellular protease production.

\section{Enzyme production}

There are several reports showing that different carbon sources have different influences on extracellular enzyme production by different strains (Chi et al., 2003). Therefore, effects of soluble starch, sucrose, glucose, lactose, fructose, maltose, corn steep meal and citric acid at the concentrations of $1 \%$ on protease production by $P S$. aeruginosa JM07 were examined. The results in Figure 1 


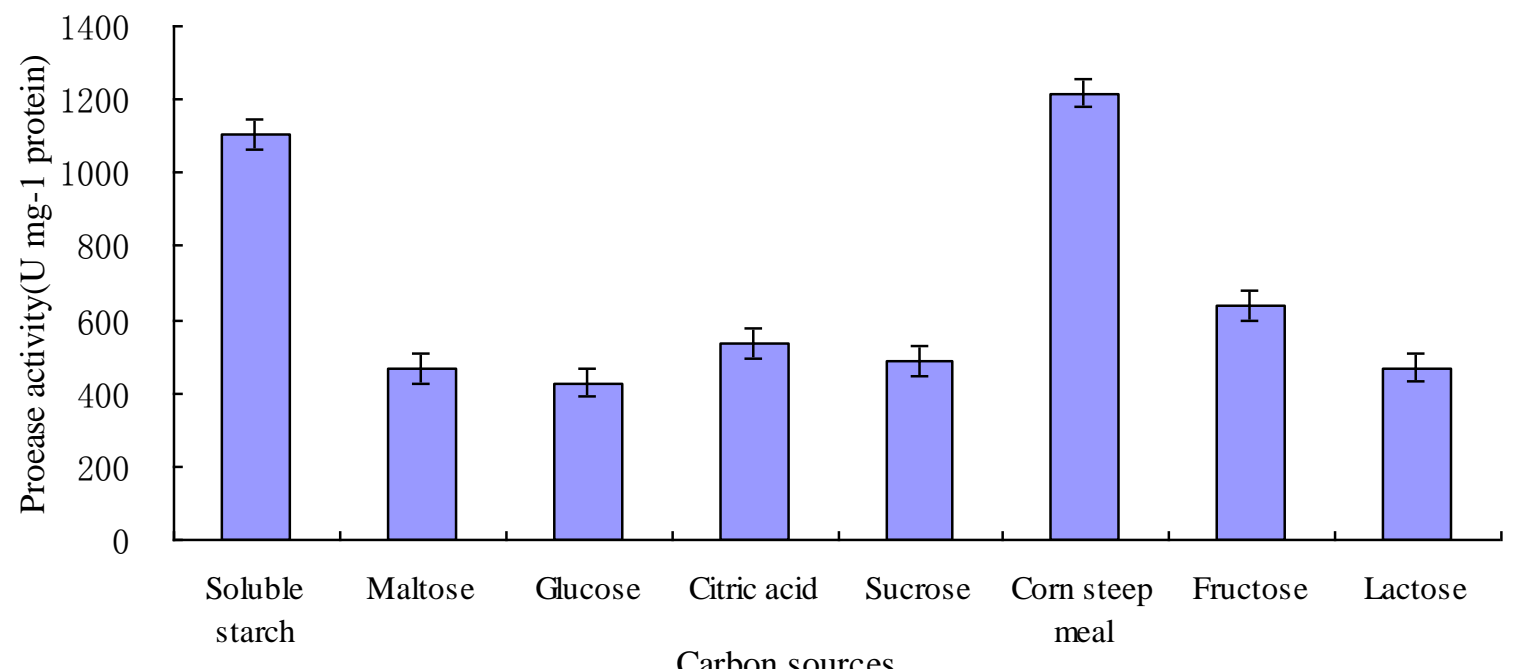

Figure 1. Effects of different carbon sources on protease production. The cells were cultivated in the production medium. All the data are given mean $\pm \mathrm{SD}, n=3$.

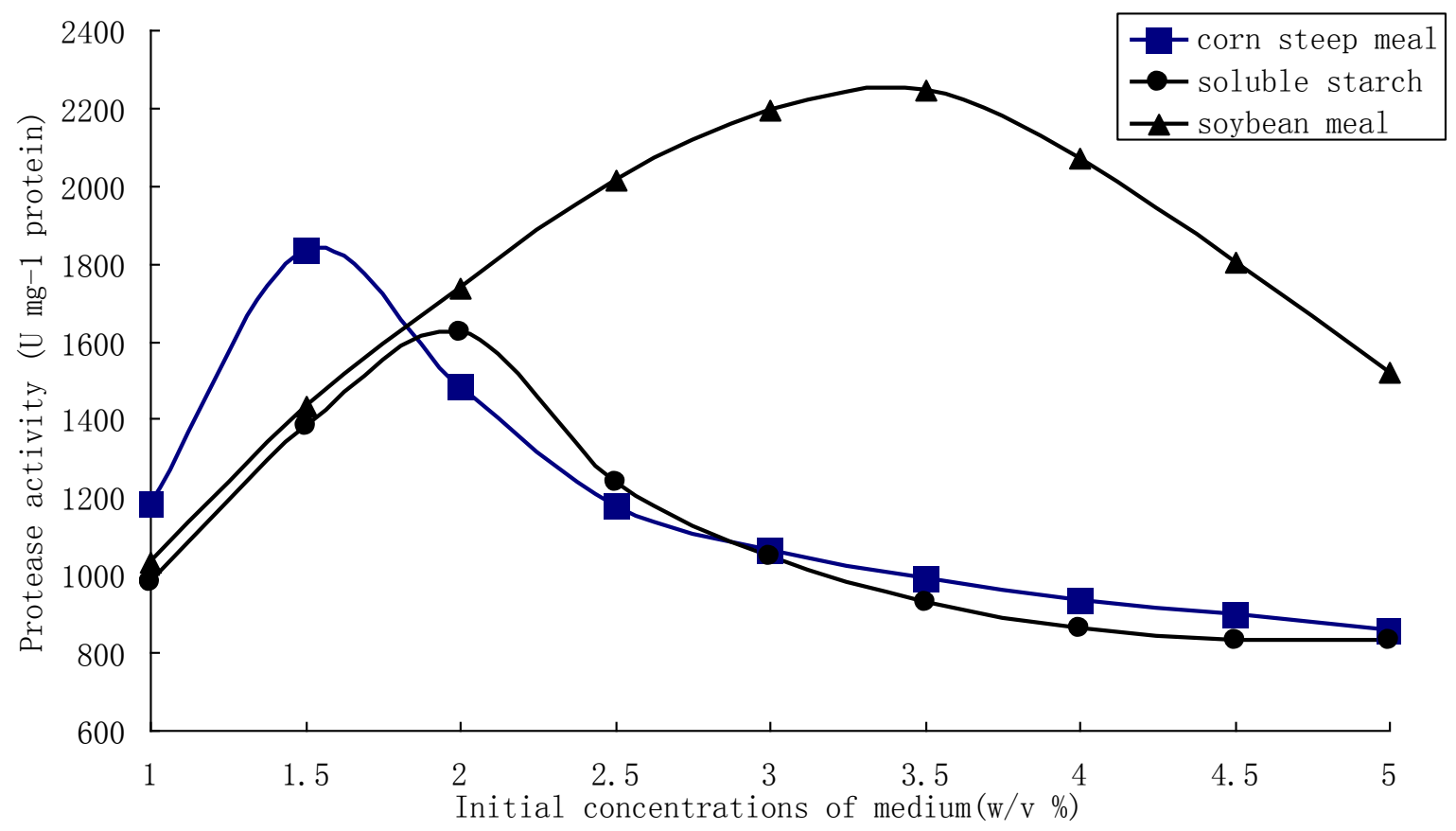

Figure 2. Effects of different initial concentrations of corn steep meal, soluble starch and soybean meal on protease production. The cells were cultivated in the production medium.

showed that corn steep meal and soluble starch were the best carbon sources for protease production. The specific protease activity in the culture supernatant was $1218 \mathrm{U}$ mg-1 protein. This meant that strain used corn steep meal as sole carbon source for protease production (Figure 1). It is thought that corn steep meal is the best carbon source for fermentation industry due to its low cost and easily obtained material. Figure 1 also showed that in the presence of other carbon sources, there was a reduction in protease production. This could be due to catabolite repression by high glucose available in the medium. However, increased yields of alkaline proteases were reported by several other workers who used different sugars such as lactose, maltose, sucrose and fructose (Jasvir et al., 2004; Canan et al., 2006). The results in Figure 2 indicated that the optimal concentration of 


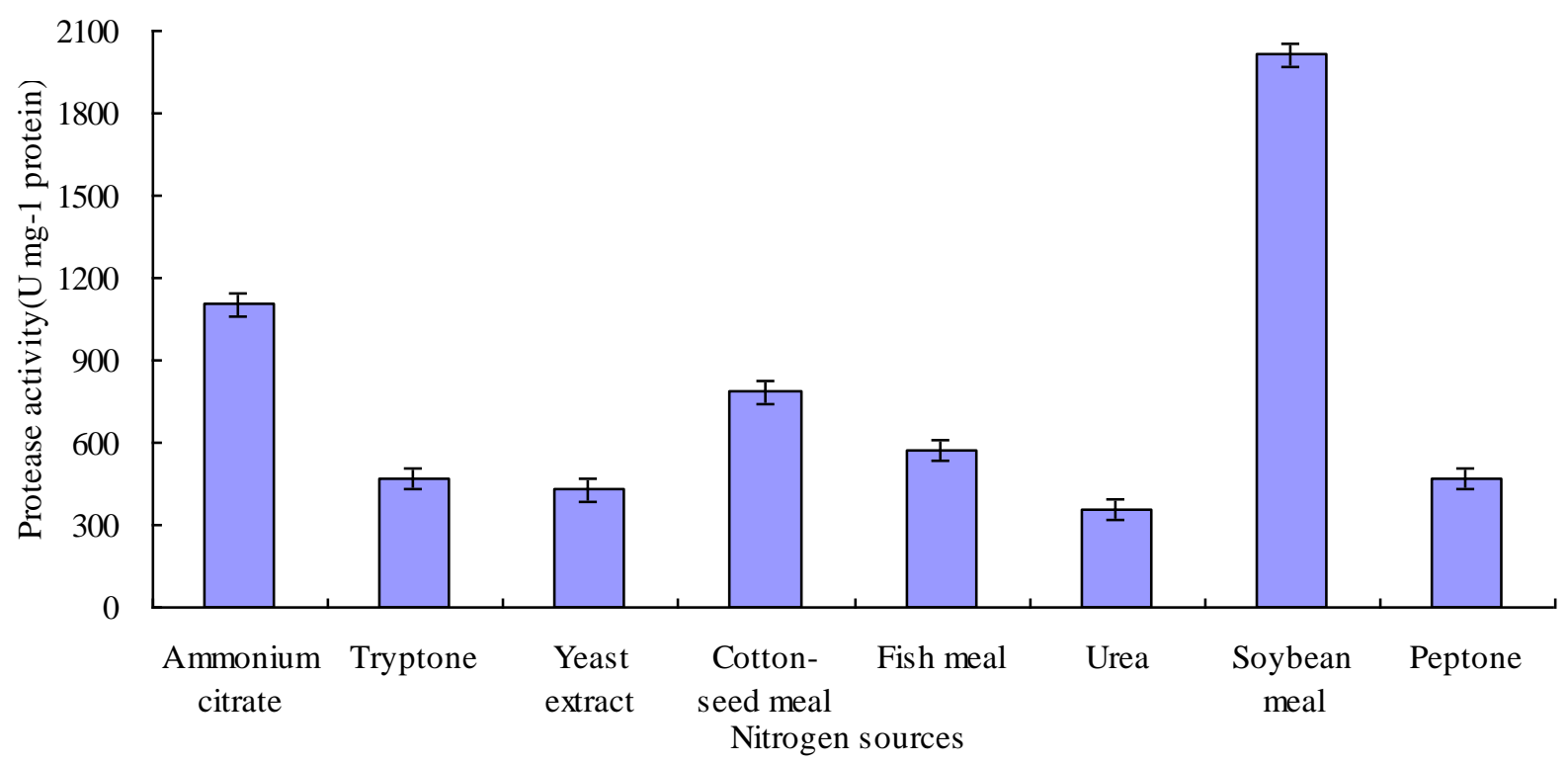

Figure 3. Effects of different nitrogen sources on protease production. Organic nitrogen concentrations used were peptone 1.5\%; fish meal 1.5\%; tryptone 1.5\%; yeast extract $1.5 \%$; urea $1.5 \%$; soybean meal $2.5 \%$; cotton-seed meal $1.5 \%$. Inorganic nitrogen concentrations were ammonium citrate $1 \%$. The cells were cultivated in the production medium. All the data are given mean $\pm S D, n=3$.

corn steep meal for the maximum protease production by the JM07 was $1.5 \%$. Under this condition, the specific protease activity reached $1835 \mathrm{U} \mathrm{mg}-1$ protein. In contrast, the optimal concentration of soluble starch for the maximum protease production was $2.0 \%$. Under this condition, the specific protease activity in the culture reached $1628 \mathrm{U} \mathrm{mg-1}$ protein, suggesting that the JM07 cells grown in the presence of corn steep meal could produce more protease than those grown in the soluble starch.

It has been reported that effects of a specific nitrogen supplement on protease production differ from organism to organism although complex nitrogen sources are usually used for alkaline protease production (Kurmar et al., 1999). Figure 3 shows that soybean meal was stimulitory for alkaline protease production by the JM07 and substitution of soybean meal in the medium with other nitrogen sources including inorganic nitrogen sources decreased greatly the enzyme production. Specific protease activity in the presence of $2.5 \%$ soybean meal reached $2013 \mathrm{U}$ mg-1 protein. The results in Figure 2 also indicated that the optimal concentration of soybean meal for the maximum protease production by the JM07 was 3.5\%. The protease activity reached the highest, $2248 \mathrm{U} \mathrm{mg}-1$.

\section{Effect of pH and thermal on activity of the enzyme}

The effects of $\mathrm{pH}$ on the protease activity toward casein were examined at various $\mathrm{pH}$ values at $30^{\circ} \mathrm{C}$ (Figure 4a). The enzyme was highly active between $\mathrm{pH} 8.0$ and 12.0 with an optimum $\mathrm{pH}$ 10.0. The relative activities at $\mathrm{pH} 8.0$ and 12.0 were about 78 and $75 \%$, respectively of that at
$\mathrm{pH}$ 10.0. The high $\mathrm{pH}$ optimum is a common characteristic of alkaline proteases (Genckal et al., 2006; Nedra et al., 2007; Raja et al., 2006). The important detergent enzymes, subtilisin Carlsberg showed maximum activity at $\mathrm{pH}$ values of 8.0-10.0 (Hadj-Ali et al., 2007). The enzyme exhibited an optimum temperature of $30^{\circ} \mathrm{C}$, with relatively high activity over a broad temperature range of $10-40^{\circ} \mathrm{C}$. The enzyme activity at 10 and $20^{\circ} \mathrm{C}$ corresponded to 70 and $85 \%$ of the maximum activity at $30^{\circ} \mathrm{C}$, which allowed lower wash temperatures when added to detergents. This protease is a true psychrophilic enzyme, both kinetically and thermodynamically adapted to cold, typical of the natural habitat of the bacteria, as proved by the following properties: low optimal temperature $\left(30^{\circ} \mathrm{C}\right)$ when compared to not only the mesophilic subtilisin Carlsberg $\left(60^{\circ} \mathrm{C}\right)$ but also to the Antarctic subtlisin S41 $\left(40^{\circ} \mathrm{C}\right)$, a high relative activity at $0^{\circ} \mathrm{C}$ corresponded to $29 \%$ of the maximum activity at $30^{\circ} \mathrm{C}$ (Figure $4 \mathrm{~B}$ ).

\section{Chemical effect}

EDTA was examined for the effect on the activity of protease. At least $10 \mathrm{mM}$ EDTA was required to inhibit protease activity more than $40 \%$. This result indicated no requirement for metal cofactors. This is due to detergents containing high amounts of sequestering agents, which could chelate the metal ions and make them unavailable in the washing solution. The effects of metal ions on the activities of the protease were investigated. The protease was activated by $\mathrm{Mg}^{2+}, \mathrm{K}^{+}, \mathrm{Ca}^{2+}, \mathrm{Ba}^{2+}$, and $\mathrm{Zn}^{2+}$. Of metal ions, the $\mathrm{Ca}^{2+}, \mathrm{Zn}^{2+}$ are very strong activators. The activi- 



Figure 4. (A) Optimum $\mathrm{pH}$ of the protease activity. Remaining activities were determined after incubating the enzyme in various buffers at different $\mathrm{pH}$ values. (B) Optimum temperature of the protease. The purified protease was incubated at various temperatures ranging from 0 to $50^{\circ} \mathrm{C}$ for $30 \mathrm{~min}$.

Table 1. Effects of various chemical reagents on the activity of enzyme.

\begin{tabular}{lcclcc}
\hline Material & Concentration $(\mathbf{m M})$ & Relative activity $(\%)$ & Material & Concentration $(\mathbf{m M})$ & Relative activity $(\%)$ \\
\hline $\mathrm{EDTA}$ & 10 & $60 \pm 2.5$ & Tris & $1(\mathrm{v} / \mathrm{v})$ & $98 \pm 2.6$ \\
& 20 & $50 \pm 2.1$ & Borax & $1(\mathrm{v} / \mathrm{v})$ & $95 \pm 2.1$ \\
$\mathrm{ZnCl} 2$ & 2 & $121 \pm 1.8$ & Triton X-100 & $1(\mathrm{v} / \mathrm{v})$ & $92 \pm 1.7$ \\
$\mathrm{CaCl} 2$ & 1 & $128 \pm 1.5$ & DFP & 1 & 0 \\
$\mathrm{KCl}$ & 1 & $105 \pm 2.2$ & PMSF & 1 & $95 \pm 1.8$ \\
$\mathrm{MgCl} 2$ & 1 & $112 \pm 1.7$ & Aprotinin & 1 & $92 \pm 2.3$ \\
$\mathrm{BaCl} 2$ & 1 & $108 \pm 2.5$ & LBTI & 1 & $96 \pm 2.5$ \\
$\mathrm{AgNO} 3$ & 1 & $42 \pm 1.3$ & SBTI & 1 & $94 \pm 2.9$ \\
& 10 & 0 & Bestatin & 1 & $78 \pm 1.5$ \\
$\mathrm{SDS}$ & $1(\mathrm{v} / \mathrm{v})$ & $43.8 \pm 1.9$ & Cystatin & 1 & $73 \pm 1.6$ \\
Tween-20 & $1(\mathrm{v} / \mathrm{v})$ & $104 \pm 2.5$ & TLCK & 1 & 100 \\
Tween-80 & $1(\mathrm{v} / \mathrm{v})$ & $108 \pm 2.3$ & TPCK & 1 & 100 \\
\hline
\end{tabular}

ties $(28$ and $21 \%)$ of the protease in the presence of $\mathrm{Ca}^{2+}$ $(1 \mathrm{mM})$ and $\mathrm{Zn}^{2+}(2 \mathrm{mM})$ were higher than that observed in the control solution. In contrast, the protease activity was completely inhibited by $\mathrm{Ag}^{+}(10 \mathrm{mM})$. The data is show in Table 1.

\section{Effects of detergent additives}

Enzymes are usually inactivated by surfactants. In the presence of $1 \% \mathrm{w} / \mathrm{v}$ SDS (anionic surfactant), the protease retained $43.8 \%$ of its activity. As for non-ionic surfactants, $1 \% \mathrm{v} / \mathrm{v}$ Tween-20 or Tween- 80 increased activity about $4-8 \%$. The other detergent additives exhibited the least inhibitory effect upon the enzyme. Since the enzyme has been shown to be stable under different surfactants, the protease could be suggested to be suitable for the wash industry. The data is show in Table 1.

\section{Protease inhibitors}

The effect of natural and synthetic inhibitors on the partially purified protease was also investigated. Enzyme activity was strongly inhibited only by DFP among the serine protease inhibitors tested, which included PMSF, aprotinin, LBTI and SBTI. In addition, bestatin and cystatin exhibited the least inhibitory effect upon the enzyme. It was also interesting to note that the trypsin selective reagent TLCK and chymotrypsin alkylating TLCK did not inhibit enzyme activity. The data is also show in Table 1. 


\section{Conclusion}

Alkaline proteases are generally produced by a wide range of microorganism including bacteria, moulds and yeasts (Ahmed et al., 2010). Alkaline proteases are the major industrial workhorses and the recent trend toward the use of alkaline proteases from these sources in different process applications like detergents, food and wool treatment has increased remarkably because of their increased production capacities, high catalytic activity and high degree of substrate specificity (Kurmar et al., 1999). Alkaline proteases are generally produced by submerged fermentation (Ahmed et al., 2010). In commercial practice, the optimization of medium composition is done to balance between the various medium components, thus minimizing the amount of unutilized components at the end of fermentation. Research efforts have been directed mainly toward evaluating the effect of various carbon and nitrogen nutrient cost-effective substrates on the yield of enzymes, requirement of divalent metal ions in the medium and optimization of environmental and parameters such as $\mathrm{pH}$, temperature, aeration and agitation (Ahmed et al., 2010). In this paper, we reported a new strain of Ps. aeruginosa JM07, which produced high levels of an extracellular alkaline protease during growth on the medium containing soybean meal $(3.5 \%$, w/v), corn steep meal (1.5\%, w/v), $\mathrm{Na}_{2} \mathrm{HPO}_{4}(0.4 \%$, w/v), $\mathrm{KH}_{2} \mathrm{PO}_{4}\left(0.03 \%\right.$, w/v), $\mathrm{Na}_{2} \mathrm{CO}_{3}\left(0.02 \%\right.$, w/v), $\mathrm{MgSO}_{4}$ $(0.02 \%, \mathrm{w} / \mathrm{v}), \mathrm{CaCl}_{2}(0.2, \mathrm{w} / \mathrm{v})$, at $\mathrm{pH} 7.0$ and $20^{\circ} \mathrm{C}$ with shaking at $200 \times \mathrm{g}$ for $12 \mathrm{~h}$.

The partially purified protease was inhibited by DFP, suggesting that it is a member of the serine protease family. The protease had an optimum $\mathrm{pH}$ of around 10 , which is a typical characteristic of alkaline proteases (Nedra et al., 2007). In comparison with the overall enzymatic properties of alkaline proteases from other sources (Chellapandi, 2010; Deng, 2008; Kurmar, 1999), the protease proved to have an excellent stability against $\mathrm{pH}$, detergents additives and chemical detergents. The high enzyme activity in alkaline $\mathrm{pH}$ at moderate temperature $\left(30^{\circ} \mathrm{C}\right)$ and stability under harsh conditions such as surfactants and heavy metals indicate that the purified enzyme is suitable for industrial purposes, especially cold wash industry.

\section{ACKNOWLEDGEMENTS}

This research work has been supported by Special Funds for the Basic R \& D Program in the Central Non-profit Research Institutes (2012A0902), International Science Cooperation Projects (No. 2011DFB30250) and Hi-Tech Research and Development Program of China (No. 2011AA090703).

\section{REFERENCES}

Ahmed I, Irfan M, Nadeem M, Zia MA, Ahmad BM, lqbal HM (2010). Optimization of Media and Environmental Conditions for Alkaline Protease Production Using Bacillus Subtilis in Submerged Fermentation Process. IJAVMS.4: 105-113.

Canan T, Hande G, Figen T (2006). Optimization of a growth medium using a statistical approach for the production of an alkaline protease from a newly isolated Bacillus sp. L21.Process Biochem.41: 659-665

Chellapandi P (2010). Production and Preliminary Characterization of Alkaline Protease from Aspergillus flavus and Aspergillus terreus. E-J Chem. 7(2): 479-482.

Chi Z., Zhao S (2003). Optimization of medium and cultivation conditions for pullulan production by a new pullulan-producing yeast. Enzyme Microb. Technol. 33:206-221

Deng JY (2008). Research progress in microbial alkaline protease. Modern Food Science and Technology.24:293-296

Genckal H, Tarib C (2006). Alkaline protease production from alkalophilic Bacillus sp. isolated from natural habitats. Enzyme Microb Tech. 39:703-710

Hadj-Ali NE, Agrebi R, Ghorbel-Frikha B, Sellami-Kamoun A, Kanoun S, Nasri M (2007). Biochemical and molecular characterization of a detergent stable alkaline serine-protease from a newly isolated Bacillus licheniformis NH1. Enzyme Microb Tech. 40:515-523.

Jasvir S, Vohra RM, Sahoo DK (2004). Enhanced production of alkaline proteases by Bacillus sphaericus using fed-batch culture. Process Biochem. 39: 1093-1101

Kurmar CG, Tagaki H (1999). Microbial alkaline protease: from bioindustrial viewpoint. Biotechnol. Adv. 17:561-594

Maurer KH (2004). Detergent proteases. Curr. Opin. Biotechnol. 15:330-334.

Nedra EH, Rym A, Basma GF, Alya SK, Safia K, Moncef N (2007). Biochemical and molecular characterization of a detergent stable alkaline serine-protease from a newly isolated Bacillus licheniformis NH1. Enz. Microbiol. Tech. 40:515-523

Nigam P, Sing D, Pandey A (2001). Utilization of agricultural and food waste and by-products by biotechnology. Agro Food Ind. Hi-Tech.12: 26-29

Raja NZ, Raja AR, Lee PG, Mahiran B, Abu BS (2006). An organic solvent-stable alkaline protease from Pseudomonas aeruginosa strain K: Enzyme purification and characterization. Enz. Microbiol. Tech. 39:1484-1491

Sugihara A, Shimada $Y$, Nomura A, Terai T, Imayasu M, Nagai $Y$, Nagao T, Watanabe $Y$ (2002). Purification and characterization of a novel cholesterol esterase from Pseudomonas aeruginosa, with its application to cleaning lipid-stained contact lenses. Biosci. Biotechnol. Biochem. 66: 2347-2355

Tekin N,Cihan AÇ,Takaç ZS, Tüzün CY,Tunç K,Çökmüş C (2012). Alkaline protease production of Bacillus cohnii APT5. Turkish J Biol. 36(4): $430-440$. 